\title{
A STUDY OF CEREBRAL PALSY IN THE CHILDHOOD POPULATION OF EDINBURGH
}

\author{
BY \\ T. T. S. INGRAM \\ From the Department of Child Life and Health, University of Edinburgh
}

(RECEIVED FOR PUBLICATION AUGUST 30, 1954)

There is increasing interest in the needs of children suffering from cerebral palsy for special education and medical treatment and for measures to render more of them employable. Many schemes to provide facilities for education and employment are being planned, but there are only a few scattered systematic surveys of the incidence of cerebral palsy in childhood, and so the size of the problem is largely unknown. This article presents the results of a recent investigation which was designed to assess the incidence of cerebral palsy in children resident in Edinburgh.

\section{The Plan of the Survey}

The survey was confined to children born in the years 1938 to 1952 inclusive who lived within the boundaries of the City of Edinburgh. Since the population of this age group in the city was more than 100,000 it was clearly impossible to examine every child individually. On the other hand, the medical services of the city work in close liaison and the school medical and public health authorities are highly developed. Due largely to the propaganda of the Scottish Council for the Care of Spastics there is a great awareness of, and interest in, the problems of the child with cerebral palsy among doctors, teachers and medical auxiliaries. Therefore children in whom cerebral palsy was suspected tended to be over-examined rather than neglected. Thus in many ways Edinburgh was an ideal city in which to obtain information about children with cerebral palsy and make a survey of its incidence.

\section{The Methods of the Survey}

Details of the children who might be suffering from cerebral palsy were obtained in three ways in the first part of the survey. First, large numbers of case notes and reports from clinicians were examined, and all cases in which cerebral palsy was suspected were noted. Secondly, all patients whose records showed that they suffered from conditions known to be associated commonly with cerebral palsy were listed. These included children with mental defect with clumsiness, epilepsy, hydrocephalus, talipes equinovarus and arthrogryposis. At the same time all patients who gave histories of having suffered from conditions likely to lead to cerebral palsy were noted. These included patients with apparent birth injury, rhesus incompatibility, meningitis, encephalitis, cerebral thrombophlebitis and head injury. Thirdly, inspections and brief examinations were made of groups of children in whom a high incidence of cerebral palsy might be expected. Thus large numbers were examined in schools for the physically and mentally handicapped, in clinics for the premature infant and in institutions for the mentally defective.

\section{Sotrces of Ascertainment}

The sources of information about possible and probable cases of cerebral palsy were very numerous and overlapped considerably. The more important sources of information will be mentioned. Access was given to the case notes of the officers of the School Medical Service, who were uniformly most helpful in providing information and facilities for the examination of their patients. In all, over 6,000 case notes were examined in various schools and over 400 patients seen in schools by arrangement with school medical officers. Information about educational difficulties and progress was obtained in as many cases as possible from teachers.

Fifty-five private schools were contacted and information sought about any children with disabilities suggestive of cerebral palsy. Replies were received from 53 of the private schools.

The officers of the Maternity and Child Welfare Service were most helpful in giving information about children they felt might be suffering from cerebral palsy, and access was given to case notes and patients in their clinics. The results of the routine health visiting of the department were also made available to the investigation. The Public Health 
Department physicians and surgeons provided information about patients with cerebral palsy visiting their clinics.

All hospitals in Edinburgh concerned with the diagnosis and treatment of children's diseases, of whatever type, and maternity hospitals in the city were contacted and in each instance ready access to case notes and patients was granted. Medical, nursing and auxiliary staff were questioned about possible cases and approximately 2,500 case notes dating back to 1940 were examined. Out-patient staffs and case notes were consulted as well as inpatient notes and staffs. Many consultants, physicians and surgeons gave access to their private patients and went to considerable trouble to arrange for the investigator to examine these children.

The Scottish Council for the Care of Spastics gave free access to their patients and records and much valuable information was obtained from the highly trained members of their staff.

The response of general practitioners to the request for information about their patients was disappointing. It was intended to contact all general practitioners in Edinburgh by letter requesting details of children who, they thought, might be suffering from cerebral palsy. As a first step, 25 practitioners were circularized and asked for information. They were known at that stage of the investigation to have at least 28 patients with cerebral palsy in their practices, but only two names were obtained and only one of these was unknown to the survey. General practitioners were not hereafter contacted specifically to obtain information about the numbers of patients with cerebral palsy in their practices, but whenever permission was sought to examine known cases doctors were always asked for details of any other cases known to them.

Other research projects amongst children in Edinburgh provided a number of cases of cerebral palsy. These included investigations of children with mental defect, of children who had suffered from meningitis, of infants with retrolental fibroplasia, the prematurely born and children who had suffered cerebral birth injury.

A few additional cases were reported by district nurses, infant clinics, speech therapists, child guidance clinics and teachers.

\section{Direct Ascertainment of Cases of Cerebral Palsy}

Direct ascertainment of children with cerebral palsy was carried out in groups of children in whom a high incidence of cerebral palsy was to be expected. The usual procedure was to watch the children at play for as long as possible and then when they attempted to sit still. Those in whom cerebral palsy was suspected on the basis of these inspections were examined. After a few months, during which experience was gained, it was found that quite as many cases of cerebral palsy were noted using this method as were discovered by detailed examination of all the children in a group.

Approximately 4,000 children were inspected in ordinary schools, special schools, nurseries, institutions for the mentally defective and infant clinics.

\section{Results of Preliminary Ascertainment}

As a result of the first part of the investigation 484 children were classified as possible cases of cerebral palsy and 165 as probable cases. Probable cases were those children who had been diagnosed as suffering from cerebral palsy by other observers or were felt to suffer from the condition as a result of the inspections of the investigator. Possible cases were those children in whom a diagnosis of cerebral palsy could not be excluded on the basis of information provided in case notes which had been inspected, or who had suffered from some condition known to lead to, or be associated with, cerebral palsy in a proportion of patients. It was felt to be desirable to examine and obtain some details of the history of the development and course of the condition in all the children in both the possible and probable categories.

Probable and Possible Cases. All the 165 children who were considered to be probable cases of cerebral palsy were examined with the exception of two for whom permission for examination was refused. In four cases a detailed history could not be obtained.

Of the 484 possible cases of cerebral palsy all but 85 were examined. Of the latter it was possible to obtain reliable information of recent medical examinations in $\mathbf{5 2}$ so that the presence of cerebral palsy could be excluded. In the remaining 33 patients it was impossible to obtain such information and it was not found possible to examine them. The 399 patients who were examined were usually seen briefly at the time of the routine school medical examination for the first time and then examined in more detail later if the presence of cerebral palsy was confirmed.

The history was obtained from the mother whenever possible and was supplemented by details of hospital admissions and clinic visits, maternity hospital and infant clinic notes and the recollections of other relatives.

In practically all the patients in the series physical examinations were performed on more than one occasion, preferably in different surroundings and preferably at intervals of a few months. Full 
clinical examinations were supplemented by special examinations, blood investigations, radiographs, intelligence tests and electroencephalograms in relatively few cases, but frequently these were available as a result of previous hospital admissions or school testing.

\section{Classification of Types of Cerebral Palsy}

The classification by neurological syndromes which was used during the survey is shown in Table 1. It will be observed that it is not based on

TABLE 1

CLASSIFICATION OF CEREBRAL PALSY IN CHILDHOOD

\begin{tabular}{|c|c|c|}
\hline $\begin{array}{l}\text { Neurological } \\
\text { Diagnosis }\end{array}$ & Extent & Severity \\
\hline Hemiplegia & $\left\{\begin{array}{l}\text { Right } \\
\text { Left }\end{array}\right.$ & $\left\{\begin{array}{l}\text { Mild } \\
\text { Moderately severe } \\
\text { Severe }\end{array}\right.$ \\
\hline Double hemiplegia & & $\left\{\begin{array}{l}\text { Mild } \\
\text { Moderately severe } \\
\text { Severe }\end{array}\right.$ \\
\hline $\begin{array}{l}\text { Diplegia } \\
\text { Hypotonic } \\
\text { Dystonic } \\
\text { Rigid or spastic }\end{array}$ & $\left\{\begin{array}{l}\text { Paraplegic } \\
\text { Triplegic } \\
\text { Tetraplegic }\end{array}\right.$ & $\left\{\begin{array}{l}\text { Mild } \\
\text { Moderately severe } \\
\text { Severe }\end{array}\right.$ \\
\hline $\left.\begin{array}{l}\text { Ataxic diplegia } \\
\text { Hypotonic } \\
\text { Spastic }\end{array}\right\}$ & $\begin{array}{l}\text { Paraplegic } \\
\text { Triplegic } \\
\text { I Tetraplegic }\end{array}$ & $\left\{\begin{array}{l}\text { Mild } \\
\text { Moderately severe } \\
\text { Severe }\end{array}\right.$ \\
\hline $\begin{array}{l}\text { Ataxia } \\
\text { Cerebellar } \\
\text { Vestibular }\end{array}$ & $\begin{array}{l}\text { Predominantly } \\
\text { Unilateral } \\
\text { Bilateral }\end{array}$ & $\left\{\begin{array}{l}\text { Mild } \\
\text { Moderately severe } \\
\text { Severe }\end{array}\right.$ \\
\hline $\begin{array}{l}\text { Dyskinesia } \\
\text { Dystonic } \\
\text { Choreoid } \\
\text { Athetoid } \\
\text { Tension } \\
\text { Tremor }\end{array}$ & $\left\{\begin{array}{l}\text { Monoplegic } \\
\text { Hemiplegic } \\
\text { Triplegic } \\
\text { Tetraplegic }\end{array}\right.$ & $\left\{\begin{array}{l}\text { Mild } \\
\text { Moderately severe } \\
\text { Severe }\end{array}\right.$ \\
\hline
\end{tabular}

single clinical features, such as alteration of muscle tone, as have many recent classifications (Phelps, 1940; Hellebrandt, 1950-51). By laying stress on single clinical features of cerebral palsy great confusion has been caused. Too close adherence to rigid classification on this basis has led to verbal absurdities like categories of 'aspastic spastics' and nosological confusions like 'cerebellar release athetosis'. Cases of hemiplegia may be found under headings of 'rigidity' and 'spasticity', though the only difference in clinical features is that contracture is more marked in the former group. It is noteworthy that, when authors using some of these complex modern classifications wish to compare series of patients suffering from different forms of palsy, they immediately resort to grouping paraplegic, triplegic and tetraplegic cases together and distinguish them from the hemiplegic forms. Yet in their classifications all these types of cerebral palsy are found together in categories of 'rigidity' and 'spasticity'. To eliminate such confusions it is desirable to resort to the earlier, well tried types of classification by neurological syndromes.

The present classification is based on that suggested by Freud $(1893,1897)$, shown in Table 2, with

TABLE 2

CEREBRAL PALSY IN CHILDHOOD AS CLASSIFIED BY FREUD (1897)

\begin{tabular}{l|c}
\hline Unilateral disorders & $\begin{array}{c}\text { Hemiplegia } \\
\text { right } \\
\text { left }\end{array}$ \\
\hline Bilateral disorders & $\begin{array}{c}\text { Diplegia } \\
\text { Paraplegic rigidity } \\
\text { Generalized rigidity } \\
\text { Bilateral hemiplegia } \\
\text { Choreoathetosis }\end{array}$ \\
\hline
\end{tabular}

Possibly other groups

some modifications rendered necessary by the widened scope of the term 'cerebral palsy' since his time, and by advances made in the knowledge of the nature of some forms of the condition. Freud included cases showing involuntary movements as the predominant clinical findings in the category of diplegia, though with some misgivings. In the present classification cases showing involuntary movements as the presenting symptom have been grouped under the heading of dyskinesia, and classified as suggested by Perlstein (1952). Largely to achieve some uniformity with contemporary American classification Freud included cases of bilateral hemiplegia under the heading of 'diplegia' (Lovett, 1888; Osler, 1889). In the present classification these cases have been placed in a separate category. In accordance with modern practice the category of ataxia has been added.

By 'diplegia' is understood a condition of more or less symmetrical paresis of cerebral origin more severe in the lower limbs than the upper and dating from birth or shortly afterwards. It will be observed that separate categories have been made for patients showing diplegia without ataxia and those showing diplegia associated with cerebellar ataxia. The aetiologies of these disorders differ, and the course and findings on examination are dissimilar.

A high proportion of patients suffering from diplegia without ataxia are born prematurely $(40 \%$ in the present series). Many show associated mental defect, epilepsy and strabismus. There is a constant pattern of development of the paresis, inadequately described in modern textbooks, in which only the final stage of diplegia, characterized by spasticity and contractures, is mentioned. In at least half the patients suffering from diplegia without 
ataxia three stages may be distinguished in the development of the final clinical picture.

For a period after birth the child may be thought to be normal, but in a proportion of patients the parents note that the baby is floppy and flaccid on handling and shows a relative poverty of movement when compared with others of the same age. On examination at this stage these patients show generalized hypotonia without any other apparent neurological abnormality in most cases. The stage of hypotonia persists for between six weeks and five months in the majority of those showing it and is succeeded by the stage of dystonia.

The stage of dystonia is first manifested by sudden generalized dystonic movements involving the trunk and limbs and precipitated by changes in the position of the child, especially extension of the head relative to the trunk. The involuntary movement consists of a sudden extension of the head and trunk, extension of the hips and knees, and plantar flexion of the feet. The upper limbs are adducted and somewhat internally rotated at the shoulders and extended at the elbows. The wrists and fingers are semiflexed and the forearms are pronated. On examination when in this position marked rigidity is found in all the muscles of the trunk and limbs. The child maintains the position of extension of the trunk and limbs for a few seconds during which time consciousness may seem slightly impaired, though it is never lost, and then the muscles again relax. Initially the sudden dystonic attacks occur relatively infrequently and only when the child's position is suddenly or grossly altered, but over a period of two or three weeks the attacks become more frequent and more readily precipitated. The generalized attacks seldom persist for less than three weeks or for longer than six months. Towards the end of the dystonic stage they become less frequent and more difficult to produce. At about the time the child is able to hold the head up steadily the generalized dystonic attacks cease in most patients and simultaneously rigidity of the limbs first becomes apparent, marking the end of the dystonic and the beginning of the rigid or spastic stage of diplegia. With the cessation of the generalized attacks the child tends to show an increase in the range and control of voluntary movements and begins to reach for objects. It is observed at this stage that though voluntary movements or changes in position no longer result in involuntary extension of the trunk, the limbs continue to assume positions similar to those noted during the earlier dystonic attacks. Rigidity is usually first evident in the thighs. It increases in a matter of a few weeks and at the same time spreads to involve the distal parts of the lower limbs and, in all but paraplegic patients, the upper limbs. The rigidity tends to result in the limbs being held in positions of predominant extension as in the earlier dystonic attacks, and these positions are accentuated by voluntary movements or passive changes in position. The phase of rigidity with predominantly extensor associated movements usually persists until the patient is able to sit without support with the knees flexed and handle objects. Commonly this is shortly before the age of 1 year in patients who are not mentally defective. The phase of rigidity merges imperceptibly into the phase of spasticity at about this stage of the child's development. The tendon jerks become increased instead of being difficult to elicit and stretch responses appear in the muscles. The Babinski responses become positive. Instead of extensor associated movements predominantly flexor associated movements accompany voluntary movements of the limbs. When spasticity is present, contracture of the limbs in flexion almost invariably follows unless the child is treated, and the final stage of diplegia is reached.

The stages which are apparent in the development of diplegic paresis appear to be of more significance than mere indications of the diagnosis. In severe cases the stage of rigidity or spasticity may never be reached and dystonic attacks may persist throughout life whenever the child attempts voluntary movement involving changes in posture. The child's neuromuscular development may be regarded as having been arrested at the relatively primitive stage of dystonia. On the other hand, the infant in whom spasticity with flexor associated movements is evident, shows neuromuscular development which may be regarded as being more mature. The child will be able to achieve more adequate motor control than will the child with persistent dystonia provided contracture is prevented. One remnant of the generalized dystonic attack persists quite commonly in patients showing predominant rigidity in the muscles and they may be regarded as being in an early phase of the rigid or spastic stage of diplegia. It is found that when these children attempt to walk a sudden extension of the neck, trunk and lower limbs ensues, a phenomenon known to physiotherapists as extensor thrust. By classifying the patient with diplegia according to the stage of the development of his condition, a clear indication is given of the maturity of his neuromuscular control.

Patients with diplegia associated with cerebellar ataxia show only two of the stages found in cases of diplegia without ataxia. Initially most of the children are hypotonic, but the majority show increasing spasticity of the limbs, more marked in 
the legs than the arms from the age of 9 or 10 months. Attacks of dystonia are never found and the predominant associated movements are flexor not extensor. The increase of tone is never rigid, but is spastic and the tendon jerks are invariably much increased. The Babinski responses are always bilaterally positive. A high proportion of these patients and their relatives are mentally defective, and in three females of the 13 patients with diplegia and cerebellar ataxia in the present series, there was a similar condition in the mother or in female siblings. On examination, in addition to the findings of paresis of the limbs, with a spastic increase of tone, there is cerebellar ataxia, which may be predominantly unilateral or bilateral.

Cases which could not be conveniently classified in any of the foregoing categories were placed in the category of 'other'. They included only two patients in the present series, one with arthrogryposis and cerebral palsy confined to the cranial nerves and one with post-encephalitic Parkinsonism.

\section{The Extent and Severity of the Palsy}

The number of limbs so severely involved neurologically that their full normal functions were impaired is stated for each category of cerebral palsy. Limbs involved neurologically but not affected severely enough to limit their functions were classified as nc mal limbs. Thus the extent of the palsy which is stated is the extent of functional impairment and not of neurological involvement. It was rare, for example, to find paraplegic patients who did not show some evidence of slight affection of the upper limbs. The side affected by hemiplegia was stated in every case.
The severity of the palsy was somewhat arbitrarily decided on the basis of different criteria for each form of cerebral palsy. Thus mild cases of hemiplegia were those in which the affected arm was capable of being used, if somewhat clumsily. Moderately severe cases were those in which the arm was useful only as an assistant to the unaffected arm, and severe cases were those in which there was very little if any functional use in the affected upper limb. Mild cases of diplegia and diplegia with ataxia were those in which the gait was clumsy but not grossly impaired. Moderately severe cases were those in which walking without support was possible but the gait was abnormal and activities were limited because of this. Severe cases were those in which walking without support was impossible or possible for only very limited distances. Mild cases of ataxia and dyskinesia were those in which the child's activities were not limited, moderately severe cases were those in which some ordinary activities, such as dressing and feeding, were possible only with difficulty. Severe cases were those in which all normal activities were severely handicapped. Bilateral hemiplegia was always a relatively severe condition. Moderately severe cases were those which could stand or walk without support. Severe cases were those in which walking was impossible, and, since the upper limbs were more handicapped than the lower limbs, the former were generally almost functionless.

\section{Incidence of Cerebral Palsy by Year of Birth}

In Table 3 is shown the incidence of cerebral palsy in Edinburgh children born between 1938 and 1952 as ascertained during the survey. It will be seen

TABLE 3

INCIDENCE OF CEREBRAL PALSY BY YEAR OF BIRTH IN EDINBURGH*

\begin{tabular}{|c|c|c|c|c|c|c|c|}
\hline \multirow{2}{*}{$\begin{array}{c}\text { Year of } \\
\text { Birth }\end{array}$} & \multirow[b]{2}{*}{ Population } & \multicolumn{3}{|c|}{ Number of Patients } & \multicolumn{3}{|c|}{ Incidence per 1,000 in 3-year Periods } \\
\hline & & Hemiplegia & Diplegia & All Types & Hemiplegia & Diplegia & All Types \\
\hline $\begin{array}{l}1938 \\
1939 \\
1940\end{array}$ & $\begin{array}{l}6,749 \\
6,574 \\
6,209\end{array}$ & $\begin{array}{r}10 \\
3 \\
3\end{array}$ & $\begin{array}{l}3 \\
8 \\
0\end{array}$ & $\begin{array}{r}17 \\
13 \\
8\end{array}$ & $0 \cdot 819$ & 0.563 & $1 \cdot 945$ \\
\hline $\begin{array}{l}1941 \\
1942 \\
1943\end{array}$ & $\begin{array}{l}6,099 \\
6,388 \\
6,538\end{array}$ & $\begin{array}{l}4 \\
4 \\
4\end{array}$ & $\begin{array}{l}2 \\
4 \\
5\end{array}$ & $\begin{array}{l}10 \\
13 \\
12 !\end{array}$ & 0.631 & $0 \cdot 578$ & $1 \cdot 839$ \\
\hline $\begin{array}{l}1944 \\
1945 \\
1946\end{array}$ & $\begin{array}{l}6,533 \\
5,993 \\
7,902\end{array}$ & $\begin{array}{l}7 \\
4 \\
8\end{array}$ & $\begin{array}{r}11 \\
3 \\
7\end{array}$ & $\begin{array}{r}24 \\
9 \\
19\end{array}$ & 0.930 & $1 \cdot 028$ & $2 \cdot 546$ \\
\hline $\begin{array}{l}1947 \\
1948 \\
1949\end{array}$ & $\begin{array}{l}8,900 \\
7,700 \\
7,500\end{array}$ & $\begin{array}{l}8 \\
6 \\
7\end{array}$ & $\begin{array}{r}7 \\
4 \\
13\end{array}$ & $\left.\begin{array}{l}21 \\
14 \\
24\end{array}\right)$ & $0 \cdot 871$ & 0.996 & $2 \cdot 448$ \\
\hline $\begin{array}{l}1950 \\
1951 \\
1952\end{array}$ & $\begin{array}{l}7,200 \\
7,100 \\
6,900\end{array}$ & $\begin{array}{l}5 \\
1 \\
1\end{array}$ & $\begin{array}{l}3 \\
6 \\
3\end{array}$ & $\begin{array}{r}11 \\
8 \\
5\end{array}$ & $0 \cdot 330$ & $0 \cdot 566$ & $1 \cdot 132$ \\
\hline $1938-52$ & 104,285 & 75 & 79 & 208 & 0.719 & $0 \cdot 757$ & $1 \cdot 991$ \\
\hline
\end{tabular}

* Based on figures obtained from the Education Authority and estimates of the Registrar-General. 
that for the two three-year periods from 1944 to 1949 the incidence of cerebral palsy is approximately 2.5 cases per 1,000 of the population. For the periods before 1944 and after 1949 the figures for incidence are lower.

The apparently lower incidence of cerebral palsy in children born between 1950 and 1952 is partly due to there being a smaller proportion of acquired cases of cerebral palsy than in those born between 1943 and 1949. Though the majority of cases of acquired cerebral palsy occur before the age of 3 , a few occur after this age, and clearly a number of children in the group born between 1950 and 1952 have yet to develop the condition. The important cause, however, of the smaller number of patients found among children born in this period compared to those born in earlier years is defective ascertainment. This is true for all the categories of the condition and for congenital as well as for acquired cases.

The reasons for defective ascertainment of patients in the younger age group are of some importance. In a large proportion of patients the early manifestations of the disorder had been misinterpreted or ignored by the doctor to whom the mother took the child. Thus in the 79 cases of diplegia in the series, 64 had symptoms before the age of 18 months. In 58 cases the symptoms resulted in the child being taken to the doctor before this age. Yet the diagnosis of some form of cerebral palsy was made in only 18 cases and the majority of patients had to wait for between 18 months and two years before diagnosis and treatment were undertaken. A delay of this duration resulting in children appearing for treatment only at the age of 3 years or more means that many have reached the stage of contracture before anything is done to limit the effects of the condition. Because the diagnosis of many patients with cerebral palsy born between 1950 and 1952 was unknown to doctors and the patients had not reached clinics or treatment centres, they were not ascertained during the survey.

The apparently lower incidence of cerebral palsy in children born between 1938 and 1943 than in those born between 1944 and 1949 appears to be due to a number of factors. It was difficult to discover why ascertainment should have been more defective for this age period than for those born in the later period. The same sources of information were available and the numbers of routine medical examinations in schools and clinics was greater in the older groups than in the younger. It might have been expected that ascertainment would be more, not less, effective in the older children. It seemed likely that the apparently lower incidence of cerebral palsy in those born between 1938 and 1943 compared with that of those born between 1944 and 1949 was either a true reflexion of a difference in the numbers of patients developing the condition or of the proportion of patients surviving in spite of it.

The death rate in children suffering from cerebral palsy is unknown, though various estimates based on unpublished or inadequate evidence have been made. It seems probable, however, that the commonest cause of death among children suffering from cerebral palsy is infection, especially of the respiratory tract in those with bulbar involvement complicating severe bilateral affection of the limbs. Since the advent of antibiotics these infections can more frequently be controlled and a higher proportion of severely affected children with cerebral palsy may be expected to survive. In the present series there is, in fact, a higher proportion of severe forms of the condition, especially diplegia of tetraplegic distribution and bilateral hemiplegia, among children born between 1944 and 1949 than in those born between 1938 and 1943.

In addition to the increase in the number of patients with cerebral palsy born in 1944-49 compared with those born in 1938-43 due to the lower death rate in the later period, there is an increase in the numbers suffering from the condition as a result of certain aetiological factors. The increase is most marked in cases of acquired ataxia and hemiplegia. The numbers suffering from the latter who were born in the periods 1938-43 and 1944-52 are shown in Table 4. It will be observed that there is

TABle 4

RELATIVE NUMBERS OF CASES OF ACQUIRED HEMIPLEGIA IN 1938-43 AND 194452 COMPARED

\begin{tabular}{c|c|c|c}
\hline Period & $\begin{array}{c}\text { No. of Cases of } \\
\text { Hemiplegia }\end{array}$ & $\begin{array}{c}\text { No. of Cases of } \\
\text { Acquired } \\
\text { Hemiplegia }\end{array}$ & $\begin{array}{c}\text { No. of Cases of } \\
\text { Acquired } \\
\text { Hemiplegia } \\
\text { Treated with } \\
\text { Penicillin }\end{array}$ \\
\hline $1938-43$ & 28 & 8 & $2 *$ \\
$1944-52$ & 47 & 25 & 17 \\
$1938-52$ & 75 & 33 & 19
\end{tabular}

* Both developed infections which were treated with penicillin after 1943.

a significantly higher proportion of patients in the second group who suffered from acquired hemiplegia, the result of the cerebral complications of acute infections. It seems probable that the effect of antibiotic therapy has been to lower the mortality from these acute infections and that a higher proportion of patients suffering from them are surviving to show the effects of cerebral damage. Similarly, there appears to be an increase in the numbers of 
patients born in the period 1944-49 compared with those born in 1938-43 who show ataxia as a result of tuberculous and septic meningitis.

It is more difficult to assess the effects on the incidence of cerebral palsy of the improvements in obstetric and infant care which have taken place since 1938. Between 1938 and 1952 the infant mortality in Edinburgh was halved. Much of this improvement was due to a reduction in the number of infants dying from infections, but the mortality from other conditions was also reduced. Unfortunately the extent of the reductions in the death rate during the past 15 years is unknown for patients with cerebral birth injury, rhesus incompatibility, and other disorders likely to result in cerebral palsy. Nor can the relative importance of these disorders in the aetiology of various forms of cerebral palsy be established in many instances. There does seem to have been an increase in the proportion of prematurely born infants surviving in the past 15 years, indicated in one Edinburgh hospital by a $39 \%$ reduction in the neonatal mortality in infants with birth weights between 3 and $5 \frac{1}{2} \mathrm{lb}$. It has been estimated that the incidence of diplegia in prematurely born children who survive is approximately $1 \%$, and a large proportion of these patients give a history of neonatal asphyxia, pulmonary atelectasis and respiratory infections (Ingram and Kerr, 1954). Clearly, if an increasing number of premature infants survive, especially of those suffering from these complications, an increase in the incidence of diplegia must be expected. When the numbers of patients with diplegia born in the periods $1938-43$ and $1944-49$ are compared, it is found that the incidence of diplegia is increased in those delivered in the later period and that a higher proportion were premature than in the earlier (Table 5).

TABLE 5

NOS. OF DIPLEGIC PATIENTS AND OF PREMATURELY BORN DIPLEGIC PATIENTS ASCERTAINED IN EDINBURGH BORN IN THE YEARS 1938-43 AND 1944-49

\begin{tabular}{c|c|c}
\hline Period of Birth & $\begin{array}{c}\text { No. of Diplegic } \\
\text { Patients }\end{array}$ & $\begin{array}{c}\text { No. of Diplegic } \\
\text { Patients Born } \\
\text { Prematurely }\end{array}$ \\
\hline $1938-43$ & 22 & 5 \\
$1944-49$ & 45 & 19 \\
\hline
\end{tabular}

It seems probable that there has been some increase in the numbers of infants surviving the effects of rhesus incompatibility and cerebral birth injury in the past 15 years, but the extent of the decrease in mortality and its effects on the incidence of cerebral palsy, and particularly of congenital hemiplegia and dyskinesia, cannot be estimated.

If the incidence of prematurely born diplegic patients, the incidence of acquired hemiplegia and the incidence of severe bilateral forms of cerebral palsy had been as high in children born between 1938 and 1943 as it was between 1944 and 1949 the figures for the total incidence of cerebral palsy in these periods would have been very similar. It seems probable, therefore, that the apparent increase in the incidence of cerebral palsy since the period 1938 to 1943 is due largely to the widespread use of antibiotics and to improved obstetric and infant care.

\section{Comparison of Incidence of Cerebral Palsy in Present Survey and with Other Surveys}

An attempt has been made to compare the incidence of cerebral palsy found during the present survey with the figures obtained during other special investigations. Some comparable figures are shown in Table 6. It will be seen that estimates of the

TABLE 6

\begin{tabular}{|c|c|c|c|}
\hline Authority & & Town & $\begin{array}{l}\text { Incidence of } \\
\text { Cerebral Palsy } \\
\text { per } 1,000\end{array}$ \\
\hline $\begin{array}{l}\text { Selected urban areas } \\
\text { British Council for the } \\
\text { of Spastics (1948) }\end{array}$ & $\begin{array}{l}\text { Welfare } \\
\text {. } \quad \text {.. }\end{array}$ & $\begin{array}{l}\text { Wallasey } \\
\text { Norwich } \\
\text { Salford } \\
\text { Oldham }\end{array}$ & $\begin{array}{l}2 \cdot 4 \\
2 \cdot 0 \\
2 \cdot 0 \\
1.9\end{array}$ \\
\hline $\begin{array}{l}\text { Cohen (1954) } \\
\text { Smallwood (1953) } \ldots \\
\text { This survey (1954) } \ldots\end{array}$ & $\begin{array}{l}. \\
\because .\end{array}$ & $\begin{array}{l}\text { Sheffield } \\
\text { Bristol } \\
\text { Edinburgh }\end{array}$ & $\begin{array}{l}1 \cdot 9 \\
2 \cdot 0 \\
2 \cdot 3\end{array}$ \\
\hline
\end{tabular}

incidence of the condition in children of school age vary between 1.9 and 2.4 cases per 1,000 of the population. A figure of between 2 and 2.5 cases per 1,000 of the school population is probably a fair estimate of the incidence of significant handicaps as a result of cerebral palsy in urban areas.

During the survey records were kept in every case of the authorities who were aware of the existence of each patient with cerebral palsy (Table 7). It was hoped to compare roughly the incidence figures of other authors whose sources of ascertainment were more limited than in the present survey. It will be observed that if only the school medical service, the public health authorities and general practitioners had been contacted, the incidence of cerebral palsy would have been approximately 1 per 1,000 of the population under the age of 15 years. With cases known to hospitals added the incidence becomes 
TABLE 7

SOURCES OF ASCERTAINMENT IN 208 PATIENTS WITH CEREBRAL PALSY IN EDINBURGH

\begin{tabular}{|c|c|c|c|}
\hline Authority & $\begin{array}{l}\text { Nos. of } \\
\text { Patients }\end{array}$ & $\begin{array}{c}\text { Cumulative } \\
\text { Totals }\end{array}$ & $\begin{array}{l}\text { Incidence } \\
\text { per } 1,000\end{array}$ \\
\hline $\begin{array}{l}\text { School medical service and } \\
\text { school for spastics } \\
\text { Public Health Department ... } \\
\text { General practitioners }\end{array}$ & $\begin{array}{r}97 \\
16 \\
1\end{array}$ & & \\
\hline $\begin{array}{l}\text { Total known to authorities } \\
\text { before present survey }\end{array}$ & & 114 & 1.094 \\
\hline 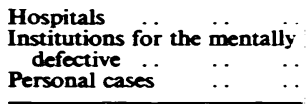 & $\begin{array}{r}52 \\
8 \\
34\end{array}$ & 156 & $1 \cdot 59$ \\
\hline Grand total . & $\cdots$ & 208 & 1.991 \\
\hline
\end{tabular}

1.59. These figures may be compared with the figures of a number of recent surveys shown in Table 8. On the basis of these figures it seems unlikely that the incidence of cerebral palsy varies greatly in different large towns though, necessarily, this conclusion must be regarded as somewhat tentative.

\section{Comparison of Proportional Distribention of Forms of Cerebral Palsy in Different Surveys}

It is rather difficult to compare the incidence of the different forms of cerebral palsy in different surveys owing to the wide variations in terminology used and to the different types of classifications which are found. In Table 9 an attempt has been made to compare some of the larger recent series of cases with those found during the present survey. Owing to the inadequate data available the reclassification of cases in other surveys is somewhat speculative.
TABLE 8

INCIDENCE OF CEREBRAL PALSY IN SCHOOL CHILDREN ASCERTAINED AS A RESULT OF LOCAL AUTHORITY RETURNS AND RECENT SURVEYS

\begin{tabular}{|c|c|c|c|}
\hline Author & Source of Data & Place & $\begin{array}{l}\text { Incidence } \\
\text { per } 1,000\end{array}$ \\
\hline $\begin{array}{c}\text { British Council for } \\
\text { the Weliare of } \\
\text { Spastics (1948) } \\
\ldots\end{array}$ & Local authorities & England & $1 \cdot 0$ \\
\hline $\begin{array}{c}\text { Asher and Schonell } \\
\begin{array}{c}\text { (1950) } \\
.\end{array}\end{array}$ & $\begin{array}{l}\text { School Medical } \\
\text { and Public } \\
\text { Health Author- } \\
\text { ities and general } \\
\text { practitioners }\end{array}$ & Birmingham & $1 \cdot 0$ \\
\hline Dunsdon (1952) & Local authorities & Various & $1 \cdot 3$ \\
\hline Holoran (1952) & $\begin{array}{l}\text { School Medical } \\
\text { and Public } \\
\text { Health Author- } \\
\text { ities, some } \\
\text { hospitals }\end{array}$ & Leeds & $1 \cdot 6$ \\
\hline
\end{tabular}

There is a considerable difference in the proportion of patients suffering from the various forms of cerebral palsy in the surveys. In general, the series based on the examination of candidates for special schools for children with a physical handicap or cerebral palsy show a higher proportion of patients with dyskinesia and a lower proportion of those with hemiplegia. The latter can more frequently manage in normal schools, whereas the former, though the majority of them are relatively intelligent, require special educational provision. Thus Evans's (1948) and Dunsdon's special school candidates show a smaller number with hemiplegia than are found in such surveys as Dunsdon's regional survey, the survey of Asher and Schonell (1950), or the present series. The lower figure obtained for the incidence of dyskinesia in the present series is also partly due to the fact that patients showing the dystonic stage

TABLE 9

PROPORTIONAL DISTRIBUTION OF VARIOUS TYPES OF CEREBRAL PALSY IN RECENT SURVEYS

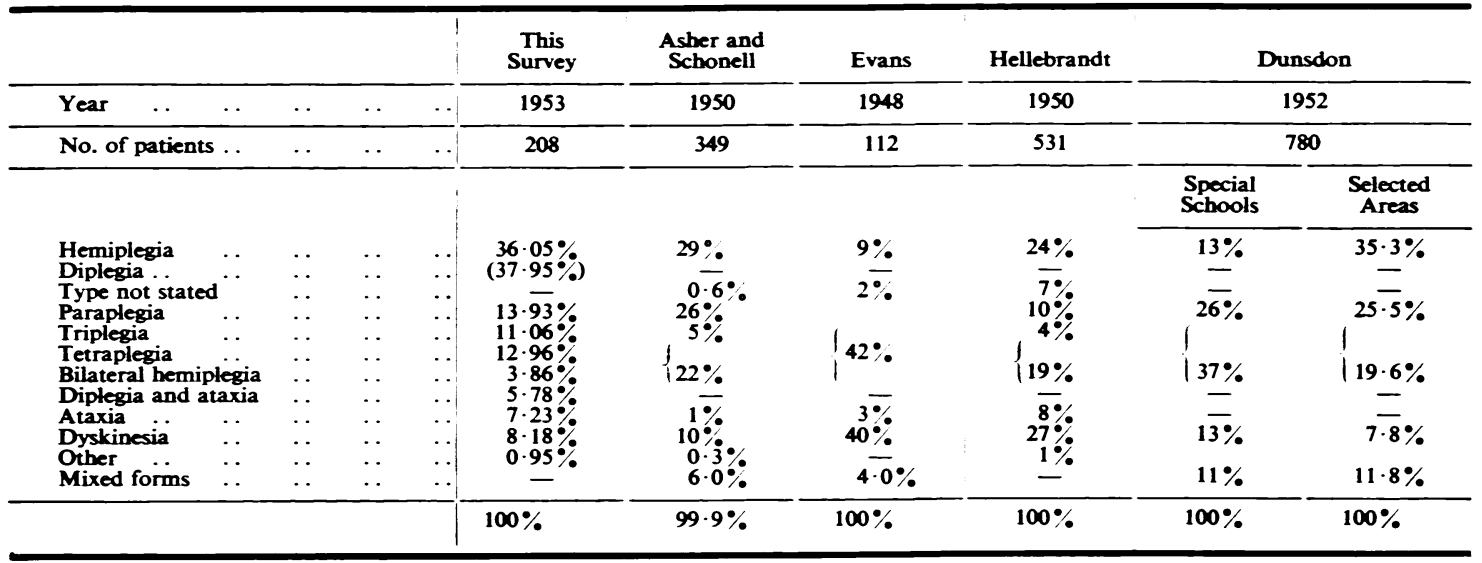


of diplegia or rigidity with some dystonic manifestations have been classified as diplegia and not as cases of dyskinesia.

It will be noted that the figures quoted for the incidence of ataxia in the present series and in that of Hellebrandt (1950) derived from a specialized cerebral palsy clinic are higher than those of the other series. This is probably due to the fact that children with quite severe cerebellar or vestibular deficit may compensate to a remarkable extent by using the eyes. In many of these patients the Romberg test is negative and very careful examination is necessary to demonstrate even moderately severe ataxia.

It is interesting that the proportional distribution of patients in the other categories of cerebral palsy in this series and in the regional surveys of Asher and Schonell and Dunsdon are broadly comparable.

\section{Sex Distribution of Cases of Cerebral Palsy}

In this series, $60.5 \%$ of the patients were males and $39.5 \%$ females. This distribution is similar to that reported in a number of other recent regional surveys (Asher and Schonell, 1950; British Council for the Welfare of Spastics, 1948). In other surveys a more equal distribution is reported (Cohen, 1954).

In the present series females outnumber males in two forms of cerebral palsy only, bilateral hemiplegia and dyskinesia. The higher proportion of males in the groups of hemiplegic patients was especially marked.

\section{The Severity of the Palsy}

In Tables 10 and 11 is shown the distribution of cases by their severity and the numbers of limbs involved. By 'normally useful upper limb' is implied a limb which can be used for normal activities, such as dressing and feeding without gross clumsiness being evident, whether neurological involvement is present or not.

It will be seen that 52 of the 208 patients $(25 \%)$

TABLE 10

SEVERITY OF CEREBRAL PALSY IN 208 PATIENTS

\begin{tabular}{|c|c|c|c|c|}
\hline Type of Palsy & $\begin{array}{l}\text { No. of } \\
\text { Mild } \\
\text { Cases }\end{array}$ & $\begin{array}{l}\text { Moder- } \\
\text { ately } \\
\text { Severe }\end{array}$ & Severe & Totals \\
\hline $\begin{array}{l}\text { Hemiplegia } \ldots \\
\text { Diplegia } \ldots \\
\text { Diplegia and ataxia } \\
\text { Ataxia } \\
\text { Dyskinesia } \ldots \\
\text { Bilateral hemiplegia } \\
\text { Other }\end{array}$ & $\begin{array}{r}27 \\
13 \\
4 \\
4 \\
4 \\
0 \\
0\end{array}$ & $\begin{array}{r}26 \\
35 \\
4 \\
8 \\
6 \\
0 \\
0\end{array}$ & $\begin{array}{r}22 \\
31 \\
4 \\
3 \\
7 \\
8 \\
1\end{array}$ & $\begin{array}{r}75 \\
79 \\
12 \\
15 \\
17 \\
8 \\
2\end{array}$ \\
\hline Totals .. & $(25 \%)$ & $\begin{array}{c}80 \\
(38 \%)\end{array}$ & $\begin{array}{c}76 \\
(37 \%)\end{array}$ & $\stackrel{208}{(100 \%}$ \\
\hline
\end{tabular}

were classified as slightly handicapped by cerebral palsy, 80 children (approximately $38 \%$ ) as moderately severely handicapped and $37 \%$ as severely handicapped. Apart from those suffering from hemiplegia severely handicapped patients usually needed assistance in looking after themselves and were unsuitable for employment in present conditions. In patients classified as being moderately severely affected, the possession of one functionally normal upper limb was of crucial importance in deciding if a child required special help in looking after himself or not.

TABLE 11

EXTENT OF CEREBRAL PALSY IN 208 PATIENTS

\begin{tabular}{|c|c|c|c|c|}
\hline Type of Palsy & $\begin{array}{l}\text { Two } \\
\text { Useful } \\
\text { Upper } \\
\text { Limbs }\end{array}$ & $\begin{array}{l}\text { One } \\
\text { Useful } \\
\text { Upper } \\
\text { Limb }\end{array}$ & $\begin{array}{l}\text { No } \\
\text { Useful } \\
\text { Upper } \\
\text { Limb }\end{array}$ & Totals \\
\hline $\begin{array}{l}\text { Hemiplegia .. } \\
\text { Diplegia } \\
\text { Diplegia with ataxia } \\
\text { Ataxia } \\
\text { Dyskinesia } \\
\text { Bilateral hemiplegia } \\
\text { Other }\end{array}$ & $\begin{array}{r}27 \\
33 \\
4 \\
15 \\
3 \\
0 \\
1\end{array}$ & $\begin{array}{r}48 \\
19 \\
6 \\
0 \\
3 \\
0 \\
0\end{array}$ & $\begin{array}{r}0 \\
27 \\
2 \\
0 \\
11 \\
8 \\
1\end{array}$ & $\begin{array}{r}75 \\
79 \\
12 \\
15 \\
17 \\
8 \\
2\end{array}$ \\
\hline Totals ... & $\begin{array}{c}83 \\
(40 \%)\end{array}$ & $\stackrel{76}{(37 \%)}$ & $(23 \%)$ & $\begin{array}{c}208 \\
(100 \%)\end{array}$ \\
\hline
\end{tabular}

\section{Associated Manifestations of Cerebral Palsy}

If paresis of the limbs was the only manifestation of cerebral palsy the vast majority of patients would be educable. It is because of the associated effects of the condition, in particular, intellectual impairment, epilepsy, speech defects, visual abnormality and specific learning difficulties, that the majority of patients need special educational help. In Table 14 some of the more important handicaps found in the series of 208 patients with cerebral palsy are recorded.

\section{Intellectual Impairment in Patients with Cerebral Paky}

Routine intelligence tests were not performed on all the patients examined during the survey, but intelligence quotients were obtained for most of those of school age from schools, hospitals and childguidance departments (Table 12). Since the estimates were obtained as a result of different tests, in the hands of different testers in differing circumstances, too much reliance cannot be placed on the results quoted. However, they are comparable to the more accurate and better controlled results obtained by other surveys (Table 13).

The majority of the children with cerebral palsy in the present series were of subnormal intelligence. Approximately $44 \%$ of the tested patients had 
TABLE 12

INTELLIGENCE QUOTIENTS OF 208 PATIENTS WITH CEREBRAL PALSY

\begin{tabular}{|c|c|c|c|c|c|c|c|c|c|c|c|c|}
\hline \multicolumn{5}{|c|}{ Intelligence Quotient } & Over 115 & $100-114$ & $85-99$ & $70-84$ & $55-69$ & Under 55 & Untested & Totals \\
\hline $\begin{array}{l}\text { Hemiplegia } \\
\text { Mild .. } \\
\text { Moderately severe } \\
\text { Severe } \quad . .\end{array}$ & $\begin{array}{l}\cdots \\
\cdots \\
\cdots\end{array}$ & $\begin{array}{l}\cdots \\
\cdots\end{array}$ & $\begin{array}{l}\cdots \\
\cdots \\
\cdots\end{array}$ & $\begin{array}{l}\cdots \\
\cdots\end{array}$ & $\begin{array}{l}1 \\
\mathbf{2} \\
\mathbf{0}\end{array}$ & $\begin{array}{l}2 \\
4 \\
4\end{array}$ & $\begin{array}{l}4 \\
2 \\
4\end{array}$ & $\begin{array}{l}4 \\
4 \\
9\end{array}$ & $\begin{array}{l}8 \\
7 \\
2\end{array}$ & $\begin{array}{l}5 \\
4 \\
2\end{array}$ & $\begin{array}{l}3 \\
3 \\
1\end{array}$ & \\
\hline Total hemipleg & gia & . & $\ldots$ & $\cdots$ & 3 & 10 & 10 & 17 & 17 & 11 & 7 & 75 \\
\hline $\begin{array}{cc}\text { Diplegia } & \\
\text { Paraplegic } & \ldots \\
\text { Triplegic } & \ldots \\
\text { Tetraplegic } & \ldots\end{array}$ & $\begin{array}{l}\ldots \\
\ldots \\
\ldots\end{array}$ & $\begin{array}{l}\cdots \\
\cdots\end{array}$ & $\begin{array}{l}\cdots \\
\cdots \\
\cdots\end{array}$ & $\begin{array}{l}\cdots \\
\cdots\end{array}$ & $\begin{array}{l}1 \\
2 \\
0\end{array}$ & $\begin{array}{l}5 \\
\mathbf{2} \\
\mathbf{0}\end{array}$ & $\begin{array}{l}4 \\
0 \\
2\end{array}$ & $\begin{array}{l}6 \\
5 \\
4\end{array}$ & $\begin{array}{l}\mathbf{7} \\
\mathbf{3} \\
\mathbf{3}\end{array}$ & $\begin{array}{r}1 \\
3 \\
11\end{array}$ & $\begin{array}{l}5 \\
8 \\
7\end{array}$ & \\
\hline Total diplegia & $\cdots$ & $\cdots$ & $\cdots$ & $\cdots$ & 3 & 7 & 6 & 15 & 13 & 15 & 20 & 79 \\
\hline $\begin{array}{l}\text { Diplegia with ataxia } \\
\text { Ataxia ... .. } \\
\text { Dyskinesia } \\
\text { Bilateral hemiplegia } \\
\text { Other . . . . }\end{array}$ & $\begin{array}{l}\cdots \\
\cdots \\
\cdots \\
\cdots\end{array}$ & $\begin{array}{l}\cdots \\
\cdots \\
\cdots \\
\cdots\end{array}$ & $\begin{array}{l}\cdots \\
\cdots \\
\cdots \\
\cdots\end{array}$ & $\begin{array}{l}\cdots \\
\cdots \\
\cdots \\
\cdots\end{array}$ & $\begin{array}{l}\mathbf{0} \\
\mathbf{0} \\
\mathbf{1} \\
\mathbf{0} \\
\mathbf{1}\end{array}$ & $\begin{array}{l}2 \\
1 \\
2 \\
0 \\
0\end{array}$ & $\begin{array}{l}3 \\
3 \\
2 \\
0 \\
0\end{array}$ & $\begin{array}{l}1 \\
6 \\
4 \\
0 \\
0\end{array}$ & $\begin{array}{l}1 \\
3 \\
2 \\
0 \\
1\end{array}$ & $\begin{array}{l}2 \\
0 \\
1 \\
8 \\
0\end{array}$ & $\begin{array}{l}3 \\
2 \\
5 \\
0 \\
0\end{array}$ & $\begin{array}{r}12 \\
15 \\
17 \\
8 \\
2\end{array}$ \\
\hline Totals ... & $\cdots$ & $\ldots$ & $\ldots$ & $\cdots$ & 8 & 22 & 24 & 43 & 37 & 37 & 37 & 208 \\
\hline Percentage dist & trib & & $\cdots$ & $\cdots$ & $3 \cdot 8$ & $10 \cdot 6$ & $11 \cdot 5$ & $20 \cdot 7$ & $17 \cdot 8$ & $17 \cdot 8$ & $17 \cdot 8$ & 100 \\
\hline Percentage dist & trib & & $\cdots$ & $\cdots$ & $4 \cdot 9$ & $12 \cdot 8$ & $14 \cdot 3$ & $24 \cdot 2$ & $21 \cdot 9$ & $21 \cdot 9$ & - & 100 \\
\hline
\end{tabular}

TABLE 13

PERCENTAGE DISTRIBUTION OF INTELLIGENCE OUOTIENTS IN THIS SURVEY COMPARFD WITH OTHER RECENT INVESTIGATIONS AND A GROUP OF UNAFFECTED SCOTTISH CHILDREN

\begin{tabular}{|c|c|c|c|c|c|c|c|c|c|c|}
\hline \multicolumn{3}{|c|}{ Intelligence Quotients } & \multirow{2}{*}{$\frac{130 \text { or More }}{0.5}$} & \multirow{2}{*}{$\frac{115 \text { to } 129}{2}$} & \multirow{2}{*}{$\frac{100 \text { to } 114}{6 \cdot 2}$} & \multirow{2}{*}{$\frac{85 \text { to } 99}{15 \cdot 5}$} & \multirow{2}{*}{$\frac{70 \text { to } 84}{17 \cdot 2}$} & \multirow{2}{*}{$\frac{55 \text { to } 69}{23 \cdot 6}$} & \multirow{2}{*}{$\frac{\text { Under } 55}{35}$} & \multirow{2}{*}{-} \\
\hline Dunsdon (1952) & .. & $\ldots$ & & & & & & & & \\
\hline \multirow[t]{2}{*}{ This survey .. } & . & $\ldots$ & $4 \cdot$ & & $12 \cdot 8$ & $14 \cdot 3$ & $24 \cdot 2$ & $21 \cdot 9$ & $21 \cdot 9$ & \\
\hline & & & 130 or More & 110 to 129 & 90 to 109 & 70 to 89 & 50 to 69 & 25 to 49 & Under 25 & Untestable \\
\hline \multicolumn{2}{|c|}{$\begin{array}{l}\text { Asher and Schonell (1950) } \\
\text { Holoran (1952) }\end{array}$} & $\begin{array}{l}\cdots \\
\cdots\end{array}$ & 0.6 & $\begin{array}{l}3 \cdot 4 \\
2 \cdot 8\end{array}$ & $\begin{array}{l}20 \cdot 1 \\
22 \cdot 0\end{array}$ & $\begin{array}{l}26 \cdot 8 \\
36 \cdot 2\end{array}$ & $\begin{array}{r}22 \cdot 9 \\
21 \cdot 3\end{array}$ & $\begin{array}{r}10 \cdot 7 \\
8 \cdot 5 \\
\end{array}$ & $\begin{array}{r}11 \cdot 6 \\
3 \cdot 5 \\
\end{array}$ & $\begin{array}{l}3 \cdot 9 \\
5 \cdot 7 \\
\end{array}$ \\
\hline \multicolumn{2}{|c|}{$\begin{array}{l}\text { Unaffected children } \\
\text { (Macmeeken, 1939) }\end{array}$} & $\ldots$ & $4 \cdot 7$ & $21 \cdot 2$ & $48 \cdot 6$ & $24 \cdot 3$ & & $1 \cdot 3$ & & \\
\hline
\end{tabular}

intelligence quotients of 69 or less. They were, therefore, in need of special educational provision whatever the severity of their palsy. Fifty-four of the patients, or $32 \%$ of those tested, had intelligence quotients of 85 or more and may, charitably, in some cases, be regarded as of normal intelligence.

\section{Incidence of Epilepsy}

In Table 15 are shown the numbers of patients who suffered from epileptic attacks of various types. Sixteen patients suffered from petit mal or similar attacks involving brief impairment of consciousness. Some of these patients also suffered from grand mal. Petit mal occurred more frequently in those with severe or extensive cerebral palsy than in those with a mild disability. It was, therefore, a nuisance to the already severely handicapped children rather than a cause, in itself, of serious limitation of activities. Grand mal and attacks of Jacksonian type with more prolonged severe impairment or loss of consciousness were present in 53 patients or approximately $25 \%$ of those suffering from cerebrai palsy. In the majority attacks occurred between once a month and once a year, in spite of antiepileptic drugs. The proportion of children suffering from severe cerebral palsy who showed epilepsy was not much higher than the proportion of mildly affected patients. The attacks were, therefore, an important cause of limitation of activities in some patients.

\section{Incidence of Speech Defects}

The crude criterion used during the present survey to determine if a child suffered from significant speech defect or not was whether comprehension of what he said was rendered difficult. Minor speech defects which were not sufficiently severe to impair comprehension of what was said were 
TABLE 14

NO. OF PATIENTS WTTH CEREBRAL PALSY BETWEEN AGES OF 6 AND 11 FOUND REVERSING LETTERS WHEN READING OR WRITING IN A SMALL EDINBURGH SURVEY

\begin{tabular}{|c|c|c|c|c|c|}
\hline $\begin{array}{l}\text { Type of } \\
\text { Palsy }\end{array}$ & $\begin{array}{l}\text { No. of } \\
\text { Patients } \\
\text { Ques- } \\
\text { tioned }\end{array}$ & $\begin{array}{l}\text { Reading } \\
\text { Only }\end{array}$ & $\begin{array}{l}\text { Writing } \\
\text { Only }\end{array}$ & $\begin{array}{l}\text { Both } \\
\text { Reading } \\
\text { and } \\
\text { Writing }\end{array}$ & Totals \\
\hline $\begin{array}{l}\text { Right bemiplegia } \ldots \\
\text { Left bemiplegia } \\
\text { Diplegia } \\
\text { Ataxia and diplegia }\end{array}$ & $\begin{array}{l}12 \\
13 \\
24\end{array}$ & $\begin{array}{l}1 \\
\mathbf{0} \\
\mathbf{0}\end{array}$ & $\begin{array}{l}4 \\
1 \\
3\end{array}$ & $\begin{array}{l}3 \\
1 \\
2\end{array}$ & $\begin{array}{l}8 \\
2 \\
5\end{array}$ \\
\hline 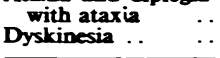 & $\begin{array}{l}5 \\
3\end{array}$ & $\begin{array}{l}\mathbf{0} \\
\mathbf{0}\end{array}$ & 2 & $\begin{array}{l}\mathbf{0} \\
\mathbf{0}\end{array}$ & $\begin{array}{l}2 \\
0\end{array}$ \\
\hline Totals & 57 & 1 & 10 & 6 & 17 \\
\hline
\end{tabular}

ignored. Generous allowance was made for retardation of speech in children with mental defect.

One hundred and two of the patients (approximately $49 \%$ were considered to suffer from significant speech defects. This may be compared to the figure obtained in one recent series where, in all, $79 \%$ of the palsied children of school age were found to suffer from speech defects, including minor defects and probably some patients with aphasia (Dunsdon, 1952). Of the patients in the present series, $10.5 \%$ had no more than one or two words of speech and are included in a total of $24.5 \%$ who had speech defects of such severity that they could not express their ideas adequately in speech.

\section{Incidence of Visual Defects}

Visual defects due to other causes than refractive errors were found in 35 patients (Table 15). The incidence of partial blindness was much higher in patients with severe cerebral palsy and mental defect than in those who were mildly affected. All eight of the patients with bilateral hemiplegia, for example, had only partial vision. In seven patients who were considered to be educable the visual defects were thought to be sufficiently severe to necessitate education by non-visual means, now or in the future. Four of these patients were suffering from retrolental fibroplasia, which was found in six patients in the series in association with diplegia. It was interesting to note the very good compensation achieved by some patients who suffered from severe field defects.

\section{Incidence of Behaviour Disorder}

The majority of the children with cerebral palsy in the present series, especially those with acquired cerebral palsy, showed functional behaviour dis-

TABLE 15

ASSOCIATED DISABILITIES AND SCHOOLING IN 208 PATIENTS SUFFERING FROM CEREBRAL PALSY

\begin{tabular}{|c|c|c|c|c|c|c|c|c|c|c|c|c|c|}
\hline \multirow{2}{*}{\multicolumn{2}{|c|}{$\begin{array}{c}\text { Classification } \\
\text { of Palsy }\end{array}$}} & \multirow[b]{2}{*}{$\begin{array}{l}\text { No. of } \\
\text { Cases }\end{array}$} & \multicolumn{2}{|c|}{ Epilepsy } & \multirow[b]{2}{*}{ Aphasia } & \multirow{2}{*}{$\begin{array}{l}\text { Visual } \\
\text { Defect }\end{array}$} & \multirow{2}{*}{$\begin{array}{l}\text { Speech } \\
\text { Defect }\end{array}$} & \multirow{2}{*}{$\begin{array}{c}\text { Over- } \\
\text { activity }\end{array}$} & \multicolumn{4}{|c|}{ Schooling } & \multirow[b]{2}{*}{$\begin{array}{c}\text { Not yet } \\
\text { at } \\
\text { School }\end{array}$} \\
\hline & & & $\begin{array}{l}\text { Grand } \\
\text { Mal } \\
\text { Jack- } \\
\text { sonian }\end{array}$ & $\begin{array}{c}\text { Petit } \\
\text { Mal and } \\
\text { Other }\end{array}$ & & & & & $\begin{array}{l}\text { Normal } \\
\text { School }\end{array}$ & $\begin{array}{l}\text { P.H. } \\
\text { School }\end{array}$ & $\begin{array}{c}\text { M.H. } \\
\text { School }\end{array}$ & $\begin{array}{l}\text { Inedu- } \\
\text { cable }\end{array}$ & \\
\hline $\begin{array}{l}\text { Hemiplegia } \\
\text { Mild . . . } \\
\text { Moderately severe } \\
\text { Severe .. } \quad \text {.. }\end{array}$ & $\begin{array}{l}\cdots \\
\cdots\end{array}$ & $\begin{array}{l}27 \\
26 \\
22\end{array}$ & $\begin{array}{r}6 \\
10 \\
8\end{array}$ & $\begin{array}{l}0 \\
4 \\
0\end{array}$ & $\begin{array}{l}2 \\
6 \\
4\end{array}$ & $\begin{array}{l}1 \\
4 \\
6\end{array}$ & $\begin{array}{r}11 \\
8 \\
2\end{array}$ & $\begin{array}{l}3 \\
4 \\
2\end{array}$ & $\begin{array}{l}9 \\
6 \\
8\end{array}$ & $\begin{array}{l}2 \\
4 \\
5\end{array}$ & $\begin{array}{l}8 \\
5 \\
2\end{array}$ & $\begin{array}{l}4 \\
1 \\
4\end{array}$ & $\begin{array}{r}4 \\
10 \\
3\end{array}$ \\
\hline Total & $\cdots$ & 75 & 22 & 4 & 12 & 11 & 21 & 9 & 23 & 11 & 15 & 9 & 17 \\
\hline $\begin{array}{l}\text { Diplegia } \\
\text { Paraplegia } \\
\text { Triplegia } \\
\text { Tetraplegia }\end{array}$ & $\begin{array}{l}\cdots \\
\cdots\end{array}$ & $\begin{array}{l}29 \\
23 \\
27\end{array}$ & $\begin{array}{l}6 \\
9 \\
7\end{array}$ & $\begin{array}{l}1 \\
3 \\
5\end{array}$ & $\begin{array}{l}\mathbf{0} \\
\mathbf{3} \\
\mathbf{1}\end{array}$ & $\begin{array}{l}2 \\
3 \\
8\end{array}$ & $\begin{array}{r}7 \\
14 \\
14\end{array}$ & $\begin{array}{l}\mathbf{0} \\
\mathbf{0} \\
\mathbf{0}\end{array}$ & $\begin{array}{l}7 \\
3 \\
1\end{array}$ & $\begin{array}{l}9 \\
3 \\
0\end{array}$ & $\begin{array}{l}5 \\
5 \\
6\end{array}$ & $\begin{array}{l}0 \\
4 \\
9\end{array}$ & $\begin{array}{r}8 \\
8 \\
11\end{array}$ \\
\hline Total & $\cdots$ & 79 & 22 & 9 & 4 & 13 & 35 & 0 & 11 & 12 & 16 & 13 & 27 \\
\hline $\begin{array}{cc}\text { Diplegia with ataxia } \\
\text { Triplegia } & \ldots \\
\text { Tetraplegia } & \text {. } \\
\end{array}$ & $\begin{array}{l}\cdots \\
\cdots\end{array}$ & $\begin{array}{l}9 \\
3 \\
\end{array}$ & $\begin{array}{l}1 \\
0\end{array}$ & $\begin{array}{l}2 \\
2 \\
\end{array}$ & $\begin{array}{l}\mathbf{0} \\
\mathbf{0}\end{array}$ & $\mathbf{0}$ & $\begin{array}{l}8 \\
2\end{array}$ & $\begin{array}{l}1 \\
0\end{array}$ & $\begin{array}{l}2 \\
\mathbf{0}\end{array}$ & $\begin{array}{l}3 \\
1\end{array}$ & $\mathbf{1}$ & $\begin{array}{l}2 \\
\mathbf{0}\end{array}$ & 1 \\
\hline Total & $\ldots$ & 12 & 1 & 4 & 0 & 1 & 10 & 1 & 2 & 4 & 2 & 2 & 2 \\
\hline Ataxia & $\cdots$ & 15 & 3 & 1 & 0 & 2 & 11 & 4 & 2 & 7 & 3 & 0 & 3 \\
\hline Dyskinesia & $\cdots$ & 17 & 0 & 4 & 0 & 0 & 15 & 1 & 2 & 7 & 2 & 1 & 5 \\
\hline Bilateral hemiplegia & $\cdots$ & 8 & 5 & $\mathbf{0}$ & 0 & 8 & 8 & 1 & $\mathbf{0}$ & 0 & 0 & 8 & 0 \\
\hline $\begin{array}{c}\text { Other forms of cereb } \\
\text { palsy } \ldots\end{array}$ & ral & 2 & $\mathbf{0}$ & 0 & 0 & 0 & 2 & 0 & 0 & 2 & 0 & $\mathbf{0}$ & 0 \\
\hline Grand total & $\cdots$ & 208 & 53 & 22 & 16 & 35 & 102 & 16 & 40 & 43 & 38 & 33 & 54 \\
\hline Percentage $\quad$. & $\cdots$ & & $28 \cdot 4$ & $10 \cdot 5$ & $7 \cdot 7$ & $16 \cdot 8$ & $48 \cdot 8$ & $7 \cdot 7$ & $19 \cdot 3$ & $20 \cdot 7$ & $18 \cdot 2$ & $15 \cdot 9$ & $25 \cdot 9$ \\
\hline Percentage of school ag & & & & & & & & & $26 \cdot 0$ & $27 \cdot 9$ & $24 \cdot 7$ & $21 \cdot 4$ & \\
\hline
\end{tabular}


order at some time or another, the result of difficulty in adapting to their disability. In addition, a number of children showed a rather typical form of over-activity which was characterized by an intense preoccupation with the immediate surroundings, gross impairment of concentration and attentionspan, and complete lack of common sense or insight. These patients were never still. All objects in the room, furniture and people attracted great superficial momentary interest. Objects were handled and frequently put to the mouth, chewed and then discarded. The over-activity appeared to be most severe up the age of 8 or 10 and then gradually to decrease. This form of behaviour disturbance was found in 16 patients and was most frequent in those with hemiplegia, especially when it affected the right side, and was associated with epilepsy (Table 15). Until the over-activity lessened most children suffering from it were ineducable.

\section{Incidence of Aphasia and Dysphasia}

Aphasia or dysphasia was evident in 16 patients (approximately $8 \%$ ) with cerebral palsy. Twelve of the patients suffered from hemiplegia, only one of them on the left. All but two of the 16 aphasic or dysphasic patients suffered from moderately severe or severe cerebral palsy, and a mild or moderate degree of mental defect was present in nine. In all, however, the degree of verbal difficulty was out of all proportion to the severity of the mental impairment. Cases of severe mental defect in which there seemed to be some specific difficulty in comprehension were classified as mental defective but not also as aphasic.

The most important effects of aphasic and dysphasic disorders were seen in the first years at school where a number of the patients were considered to be defective until careful intelligence testing was performed.

\section{Specific Learning Difficulties in Children with Cerebral Paky}

In addition to the handicaps imposed on the child's ability to learn by motor impairment, visual defects, aphasia and speech defects a number of patients showed specific educational difficulties. Some appeared to have great difficulty in recognizing and forming letters, numbers and shapes of small words, and learning to read and write was therefore much retarded. Mild manifestations usually last only a few months and take the form of reversals of letters and small words in writing, and, less commonly, in reading. In its more severe forms, however, the learning disability deserves the name of true word-blindness. Ataxic patients appeared to show particular difficulty in writing letters, and letter reversals and word inversions were especially frequent and severe.

It was impossible to obtain details of the early educational progress of all the children in the survey, but in 57 patients, whose intelligence quotients varied from 60 to 125 , details were obtained and the results are shown in Table 14. It will be seen that a relatively high proportion of patients, especially those with right hemiplegia, showed directional confusions in writing.

A high proportion of patients with cerebral palsy showed rather poor powers of concentration and a very limited attention span, even when intellectual impairment was relatively slight. Very skilful teaching is necessary.

\section{The Education of Children with Cerebral Palsy}

In Table 15 are shown the numbers of children of school age in the series who attended various types of school or were classified as ineducable. The figures obtained during this survey were compared with those of other similar surveys. The proportions of children in different schools vary in different surveys. This is probably a reflexion on the selective nature of some series and of the differences in the types of schools available in different districts rather than a measure of differences in the types of handicap suffered by children in different areas. Nevertheless, the surveys show that not more than one quarter of the children who suffer from cerebral palsy are capable of benefiting from normal educational methods. Only three patients in the present series were thought to be capable of taking their higher leaving certificates. Over half the patients in normal schools suffered from hemiplegia and, therefore, had at least one functionally normal upper limb. In contrast, only 11 patients with diplegia were in normal schools and there was tetraplegic paresis in only one of these. In general, types of cerebral palsy which tended to involve all limbs resulted in a smaller proportion of children in normal schools. Thus, in spite of the relatively less severe mental impairment than in other forms of cerebral palsy, only two patients with dyskinesia were in normal schools. Of the 12 patients of school age who showed ataxia, there were only two in normal schools.

Thirty-three of the patients of school age (approximately $21 \cdot 5 \%$ were classified as ineducable. In practice this category was found to consist almost entirely of severely mentally defective children. Thirteen of the patients classified as ineducable were in institutions for the mentally defective. The 
remainder were in occupation centres or at home. Twenty-one were bedridden and in need of constant care and attention. Eighty-one of the patients of school age $(52.6 \%)$ attended special schools for the mentally or physically handicapped. The decision as to which type of school was best for the child was decided on the basis of the relative severity of the palsy and of the intellectual impairment. Though there was some overlapping of the types of case found in these schools; in general, those with intelligence quotients of under 70 were found in schools for the mentally handicapped and those with intelligence quotients of over 70 were in schools for the physically handicapped. Forty-three children, approximately $28 \%$ of those of school age, were in schools for the physically handicapped, of whom six were in residential schools.

\section{Prospects of Regular Employment for Children with Cerebral Paky}

During the survey some experience was gained of the employment difficulties encountered by a number of patients between the ages of 16 and 18 who suffered from cerebral palsy. On the basis of this experience an attempt was made to assess the prospects of regular employment and the need for care of the cases of school age ascertained during the survey. Patients were placed in three categories, probably employable, possibly employable, or unemployable (Table 16).

The majority of patients who attended normal schools were considered to be probably employable with the exceptions of two relatively severely affected patients with diplegia, who were placed in the 'possibly employable' group. Three patients with hemiplegia and two with diplegia in schools for the physically handicapped were felt to be probably employable. In all 43 patients, or $28 \%$ of those of school age, were considered to be probably employable.

Patients with intelligence quotients of less than 70 were automatically classified as unemployable. Because of intellectual impairment they were only fitted for unskilled manual work, which they were unable to do on account of their physical handicaps. Patients with intelligence quotients of between 70 and 85 might be expected to be suitable for unskilled work, but the majority would only be capable of this if the palsy was of a relatively slight degree. Therefore those who were moderately severely or severely affected were classified as unemployable, and patients with mild cerebral palsy were classified, somewhat optimistically, as being possibly employable. In all 86 patients, approximately $56 \%$ of those of school age, were classified as unemployable.

Twenty-five patients were classified as possibly employable, $16 \%$ of those of school age. Two cases in this category came from normal schools, 20 from schools for the physically handicapped, including five patients with ataxia and six with dyskinesia. Three patients came from schools for the mentally handicapped. They had intelligence quotients of between 70 and 85 and relatively mild cerebral palsy.

TABLE 16

ASSESSMENT OF PROSPECTS OF EMPLOYMENT IN PRESENT CIRCUMSTANCES OF 154 CHILDREN OF SCHOOL AGE WITH CEREBRAL PALSY

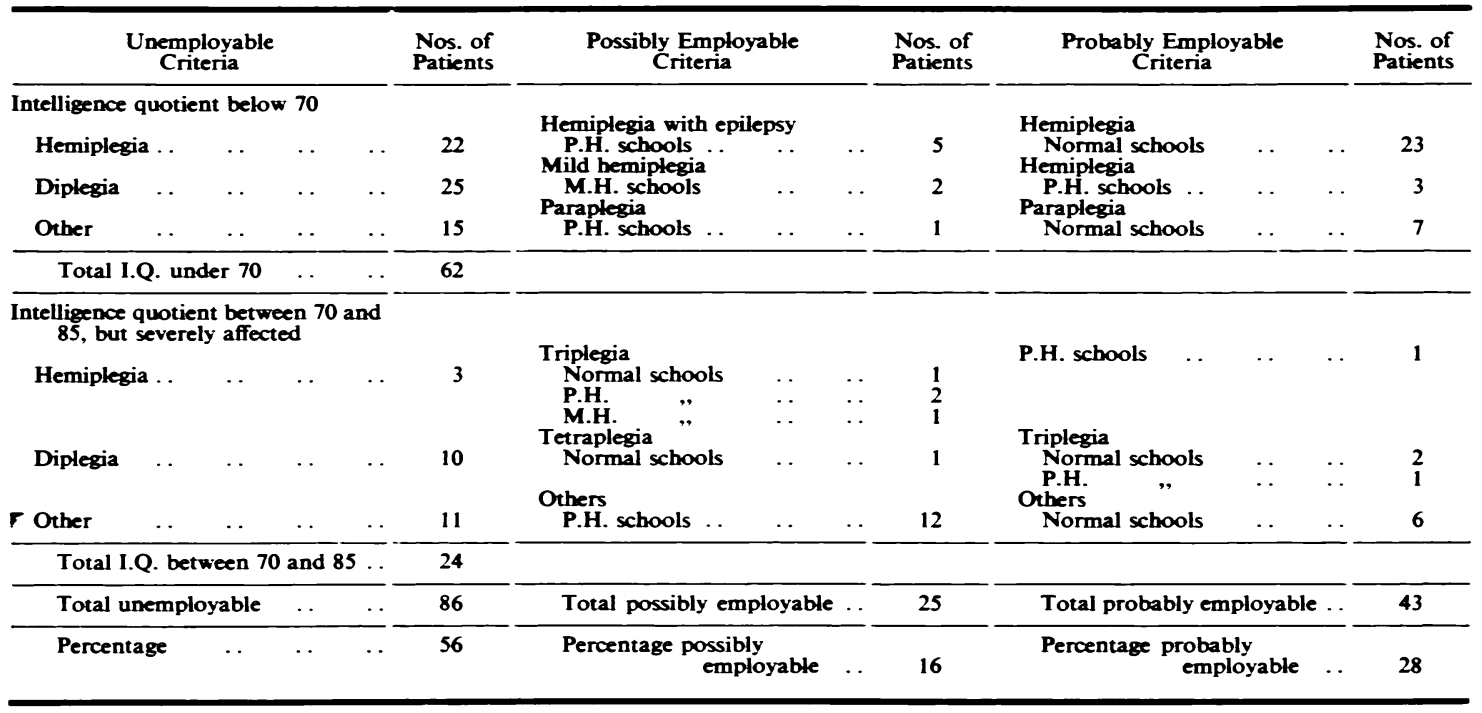


It seems clear from this somewhat speculative assessment of the chances of regular employment for children with cerebral palsy that not more than one-third are likely to be self supporting in present conditions. A number of the patients who do obtain regular work will obtain only jobs in which prospects are poor. In present labour conditions relatively few of the $16 \%$ of children in the 'possibly employable' group are likely to obtain regular employment, though in favourable conditions and under some form of supervision many might make a contribution to their own maintenance.

The $56 \%$ of patients in the unemployable group are unlikely to be able to make any contribution to their own maintenance. The majority will be in need of constant care for many years. Twenty-one of the patients in this group are bedridden and probably all will eventually be in need of constant nursing attention in institutions.

\section{Summary and Conclusions}

A description has been given of a recent survey in Edinburgh designed to ascertain the incidence of cerebral palsy in children born between 1938 and 1952. Evidence is presented which suggests that the incidence is between 2 and $2 \cdot 5$ cases per 1,000 children, and this estimate is compared with the incidence of the condition found in other surveys.

The number of children suffering from cerebral palsy born between 1950 and 1952 who were ascertained was small. It is shown that this is largely due to the present great delay in the diagnosis of children with early symptoms of cerebral palsy.

A smaller incidence of cerebral palsy was found in the six-year period 1938 to 1943 than in the period 1944 to 1949 . It is suggested that the difference in incidence is partly due to more patients with cerebral palsy born in the later period surviving because complicating infections could be controlled by antibiotics. A more important cause of the greater incidence amongst children born between 1944 and 1949 is the fact that the survival rate for those suffering from conditions likely to lead to cerebral palsy was increased in this period by improvements in infant care and the widespread use of antibiotics.

The severity of the handicaps imposed on the child because of cerebral palsy and associated physical and mental abnormalities are described. The relatively low proportion of patients capable of benefiting from normal educational methods, and the high proportion who are likely to be a burden to the community throughout life is stressed. An assessment is presented of the numbers of patients likely to obtain regular employment eventually and the numbers who will require care and attendance.

It is pointed out that earlier diagnosis and treatment of children with cerebral palsy might lead to a reduction of the physical handicap resulting from contractures of the limbs. Though not likely to be financially rewarding, it is apparent as a result of the survey that much more attention must be paid to obtaining training and employment, if necessary under supervision, for patients with cerebral palsy.

This survey could not have been made without the cooperation of so many physicians and surgeons in Edinburgh that it is impossible to mention them individually. I am especially grateful to Dr. W. N. Boog Watson, of the School Medical Service, and Dr. H. P. Tait, of the Maternity and Child Welfare Service, for their unfailing help, and to the paediatricians of the Royal Hospital for Sick Children and Western General Hospital, Edinburgh. I owe thanks to the records officers of these and other hospitals and institutions, and to Miss E. Cruickshank for much secretarial assistance.

I am deeply indebted to Professor R. W. B. Ellis for his guidance and encouragement during the survey and for his help during the preparation of this paper.

\section{REFzrences
Asher, P. and Schonell, F. E. (1950). Archives of Disease in Childhood, 25, 360 . \\ British Council for the Welfare of Spastics (1948). The Incidence of Cerebral Palsy. Unpublished typescript. \\ Cohen, H. M. (1954). The Incidence of Cerebral Palsy Amongst School Children in Sheffield. Personal communication.}

Dunsdon, M. I. (1952). The Educability of the Cerebral Palsied Child. London.

Edinburgh Education Committee. Annual progress Reports. City and Royal Burgh of Edinburgh.

Evans, P. R. (1948). Archives of Disease in Childhood, 23, 213.

Freud, S. (1893). Zur Kenntniss der Cerebralen Diplegien des Kindesalters. Vienna.

(1897). Die Infantile Cerebrallahmung. In Specielle Pathologie und Therapie, ed. Nothagel, H., Vol. 9, Pt. 2(2). Vienna.

Hellebrandt, F. A. (1950-51). Trends in the Management of Cerebral Palsy. Lectures in the Medical College of Virginia. Unpublished typescript.

Holoran, I. M. (1952). Brit. med. J., 1, 214.

Ingram, T. T. S. and Kerr, J. D. (1954). Archives of Disease in

Childhood, 29, 282.
Lovett, R. W. (1888). Boston med. surg. J., 118, 641.

Macmeeken, A. M. (1939). The Intelligence of a Representative Group of Scottish Children. London.

Medical Officer of Health. City of Edinburgh. Annual reports of the Public Health Department.

Osler, W. (1889). The Cerebral Palsies in Children. London.

Perlstein, M. A. (1952). J. Amer. med. Ass., 149, 30.

Phelps, W. M. (1940). Med. Rec., 152, 216.

(1941). J. Amer. med. Ass., 117, 1621.

Registrar-General for Scotland. Annual reports. H.M. Stationery Office, Edinburgh.

Smallwood, A. L. (1953). Quoted in Welfare of Handicapped Persons; the Special Welfare Needs of Epileptics and Spastics. Ministry of Health, Circular 26.53. 